Article

\title{
Bio-Removal of Methylene Blue from Aqueous Solution by Galactomyces geotrichum KL20A
}

\author{
Margarita Contreras ${ }^{1}$, Carlos David Grande-Tovar ${ }^{1, *} \mathbb{\infty}$, William Vallejo ${ }^{1} \mathbb{C}$ and \\ Clemencia Chaves-López ${ }^{2}$ \\ 1 Grupo de Fotoquímica y Fotobiología, Universidad del Atlántico, Puerto Colombia 81007, Colombia; \\ contreras.margui@yahoo.es (M.C.); williamvallejo@mail.uniatlantico.edu.co (W.V.) \\ 2 Faculty of Bioscience and Technology for Food, Agriculture and Environment, University of Teramo, Via R. \\ Balzarini 1,64100 Teramo, Italy; cchaveslopez@unite.it \\ * Correspondence: carlosgrande@mail.uniatlantico.edu.co; Tel.: +57-5-3599484
}

Received: 23 October 2018; Accepted: 7 January 2019; Published: 6 February 2019

\begin{abstract}
The conventional treatments used to remove dyes produced as a result of different industrial activities are not completely effective. At times, some toxic by-products are generated, affecting aquatic ecosystems. In this article, an efficient use of microorganisms is presented as a biodegradation technique that is a safe environmental alternative for the benefit of aquatic life. A strain of the yeast Galactomyces geotrichum KL20A isolated from Kumis (a Colombian natural fermented milk) was used for Methylene Blue (MB) bioremoval. Two parameters of the bioremediation process were studied at three different levels: initial dye concentration and growth temperature. The maximum time of MB exposure to the yeast was $48 \mathrm{~h}$. Finally, a pseudo-first-order model was used to simulate the kinetics of the process. The removal percentages of MB, by action of G. geotrichum KL20A were greater than $70 \%$ under the best operating conditions and in addition, the kinetic simulation of the experimental results indicated that the constant rate of the process was $2.2 \times 10^{-2} \mathrm{~h}^{-1}$ with a half time for biotransformation of $31.2 \mathrm{~h}$. The cytotoxicity test based on the hemolytic reaction indicated that by-products obtained after the bioremoval process reached a much lower percentage of hemolysis $(22 \%)$ compared to the hemolytic activity of the negative control $(100 \%)$. All of these results suggest that the strain has the capacity to remove significant amounts of MB from wastewater effluents.
\end{abstract}

Keywords: bioremediation; dyes; Galactomyces geotrichum; methylene blue

\section{Introduction}

Most of the industrial effluents in developed countries have a high load of xenobiotic compounds, such as dyes. These compounds are recalcitrant, difficult to biodegrade, and toxic to aquatic species, animals, and human beings. Most of the dyes used in the textile industry are stable, resistant to biological, physical, and chemical treatments, implying that their complete removal is difficult. Due to their high solubility in water, they cause contamination in local aquatic systems when they are discharged directly without prior treatment [1]. In particular, Azo dyes are the largest synthetic chemical class of dyes that are characterized by the presence of one or more azo bonds $(-\mathrm{N}=\mathrm{N}-)$. They are used to a great degree in textile, pharmaceutical, leather, food, cosmetic, painting, and large-scale printing industries due to their ease of synthesis and stability [2]. MB is an aromatic heterocyclic used in different applications (e.g., medicine [3], biological [4], and textile industries [5]). Currently, MB dye is one of the most commonly used substances for dyeing cotton, wood, and silk [6]. The dye is commonly found in industrial wastewater, which causes devastating effects on the environment [7]. Given the characteristics of solubility and stability of azo dyes, traditional methods of flocculation, sedimentation, or adsorption are not efficient in the removal of these compounds because they only 
transfer matter between different phases without effective degradation of the compounds [8]. Currently, such physicochemical methods are the most important ones used for the treatment of wastewater produced by the textile industry, resulting in effluents of acceptable quality, while at the same time generating waste products with high levels of toxicity. For this reason, research on the application of biological processes as a method of dye degradation has been intensified in recent years due to the resulting low toxicity. Their high efficiency $[9,10]$, which is due in part to the inherent capacity of the microorganisms to break down organic pollutants by using them as a source of carbon and energy, or by co-metabolism [11,12], has also contributed to intensified research. The use of yeasts for the bioremoval of toxic compounds has many advantages in comparison to filamentous bacteria and fungi, since they grow rapidly and have the capacity to adapt and resist unfavorable environments [13]. The Geotrichum spp. is a filamentous fungus (Phylum Ascomycota, Order Saccharomycetales) that has transparent spores by segmentation of vegetative filaments [14]. G. geotrichum is a holomorphic organism, which means that it presents two forms of reproduction (sexual and asexual): the asexual form of multiplication gives rise to the anamorph (Geotrichum candidum) or imperfect state, while the sexual form gives rise to the teleomorph (G. geotrichum) or perfect state. These fungal species are capable of alternating a unicellular phase (yeast growth) with another mycelium (hyphae) in response to changes in various environmental factors (nutrients, $\mathrm{CO}_{2}$ pressure, $\mathrm{pH}$ changes, temperature). They are called "dimorphic fungi" and tend to proliferate as yeasts in tissues. However, they assume filamentous forms at room temperature in the environment [15]. This fungus is present in diverse habitats. It is found as a component of the natural flora in milk and is used as a ripening agent for cheese. Furthermore, it presents colonies of fast growth (four days of maturation), and of unlimited size. G. geotrichum is white and has a moist, yeast-like, appearance, and is easy to obtain. This yeast is characterized by true hyphae, thick (macrosiphonated) forming numerous arthroconidia, hyaline, and rectangular. The absence of blastoconidia differentiates it from the genus Trichosporon spp. [16]. Their lipases and proteases produce fatty acids and peptides that can be metabolized by other microbial populations, promoting the development of different aromas [17]. G. geotrichum can be considered one of the fungi with a large number of biotechnology applications. In fact, $38 \%$ of the publications which refer to this organism mention its capacity to biodegrade toxic compounds and its application in bioremediation processes in the treatment of wastewater for the improvement of the environment [18]. For G. geotrichum MTCC (registered at Microbial Type Culture Collection and Gene Bank, MTCC) a $100 \%$ efficiency in methyl red discoloration was reported after one hour at $30{ }^{\circ} \mathrm{C}$. The composition of malt yeast medium used for decolorization studies was malt extract $(3.0 \mathrm{~g} / \mathrm{L})$, yeast extract (3.0 g/L), peptone $(5.0 \mathrm{~g} / \mathrm{L})$, and glucose $(10.0 \mathrm{~g} / \mathrm{L})(\mathrm{pH} 7.0)$ [19], while Waghmode et al. reported the decolorization of the azo dye Rubine by G. geotrichum MTCC 1360 within $96 \mathrm{~h}$ from exposure at $30^{\circ} \mathrm{C}$ and $\mathrm{pH} 7.0$ [20]. Govindwar et al. also reported a reduction of $86 \%$ via discoloration of the RY-84A dye at $50 \mathrm{mg} \mathrm{L}^{-1}$ after $30 \mathrm{~h}$ of exposure [21]. Despite extensive studies on different microorganisms for the development of biotechnological applications, this is the first time that removal of MB with G. geotrichum KL20A has been reported.

In this work, the removal of MB dye with G. geotrichum KL20A was studied in order to search for alternative methods of water treatment that would be environmentally friendly and safe.

\section{Materials and Methods}

\subsection{Yeast Isolation and Culture}

The yeast G. geotrichum KL20A was isolated from traditional Kumis samples collected in Valle del Cauca (in the southwest of Colombia) as reported by Chaves-López et al. [22]. The identification was carried out by sequencing of the D1/D2 region of the 26S rRNA gene and by random amplification of polymorphic DNA (RAPD-PCR). Subsequently, it was sequenced and compared with the data available in The European Molecular Biology Laboratory (EMBL) nucleotide sequence database. The strain was maintained in Petri dishes containing $12 \mathrm{~mL}$ of YPD-agar medium $(10 \mathrm{~g} / \mathrm{L}$ yeast extract, 
$20 \mathrm{~g} / \mathrm{L}$ dextrose, $20 \mathrm{~g} / \mathrm{L}$ peptone, $20 \mathrm{~g} / \mathrm{L}$ agar) and periodically reactivated for $24 \mathrm{~h}$ at $30{ }^{\circ} \mathrm{C}$ in the same growth medium $[19,21]$. A suspension cell solution was then prepared in YPD-broth (without agar) and a chamber count was performed using a Neubauer chamber to control the concentration of the yeast (approximately $3.2 \times 10^{7} \mathrm{cel} / \mathrm{mL}$ ) to be used in the removal tests. The Neubauer chamber remains the most common method for cell counting around the world, also known as hemocytometer.

\subsection{Removal Tests}

\subsubsection{Effects of the Methylene Blue Concentration and Temperature}

Methylene Blue dye (MB CI 52015 from Merck KGa, Darmstadt, Germany) was used to prepare a stock solution of $3.13 \mathrm{M}(1000 \mathrm{ppm}, \mathrm{pH}$ 7.3) by dissolving the required amount of the dye in sterile distilled water. Concentrations of 50,100, and 200 ppm were used for the removal tests. To this end, sterilized tubes containing $1 \mathrm{~mL}$ of YPD-broth medium ( $\mathrm{pH} 7.0)$ were added to the appropriate MB concentrations (50 ppm, $100 \mathrm{ppm}$, and $200 \mathrm{ppm}$ ) and inoculated with $3.2 \times 10^{7} \mathrm{cells} / \mathrm{mL}$ of $G$. geotrichum KL20A. Decolorization of MB was studied at $25^{\circ} \mathrm{C}, 30^{\circ} \mathrm{C}$ and $35^{\circ} \mathrm{C}$ for $48 \mathrm{~h}$. Periodically, $160 \mu \mathrm{L}$ of the samples were transferred into a 96 well microplate and the absorbance at $660 \mathrm{~nm}$ was read using Elisa SPR-960 reader [23]. The removal tests were carried out in triplicate with their respective targets, under the strictest biosecurity conditions to preserve the asepsis of the experiments.

\subsubsection{Effects of the $\mathrm{pH}$}

In order to study the effect of the $\mathrm{pH}$ on the discoloration of the $\mathrm{MB}$, we performed the experiment using the optimal conditions of concentration and temperature to degrade $\mathrm{MB}\left(50 \mathrm{ppm}, 35^{\circ} \mathrm{C}\right)$. Thus, we modified the above-mentioned $\mathrm{pH}$ of the medium to achieve values of 5,7 , and 9 using $\mathrm{HCl} / \mathrm{NaOH}$ $0.1 \mathrm{~N}$ solutions. The $\mathrm{pH}$ was measured with a Thermo-Fisher Scientific $\mathrm{pH}$ meter, previously calibrated

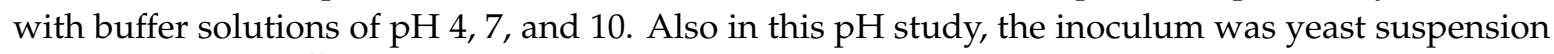
containing $3.2 \times 10^{7}$ cells $/ \mathrm{mL}$.

Finally, biodegradation kinetics were investigated during the $48 \mathrm{~h}$ and a pseudo-first-order model was used to simulate the data and derive the biodegradation rate constant.

\subsection{Citotoxicity Analysis}

The evaluation of the toxicological impact of the MB dye and its metabolites, was carried out through a hemolytic activity test following the methodology cited by Zhen [24] with some modifications as follows: the negative control was phosphate-buffered saline (PBS) (pH 7.2) treated erythrocytes (this buffer protects the erythrocytes against lysis), and the positive control was a solution of $0.1 \%$ of Triton-X-100 (Sigma, Milwaukee, WI, USA), a surfactant reagent that is well known to cause cell lysis. The solution was prepared according to the manufacturer's recommendations). Spectrophotometric analysis was used to measure the absorbance of free hemoglobin $(545 \mathrm{~nm})$ in a Thermo Genesys $10 \mathrm{~S}$ UV/VIS spectrophotometer. The hemolytic activity was reported as percentage of hemolysis (\% Hem) evaluated using the following equation:

$$
\% \text { Hem }=\frac{\mathrm{A}_{\mathrm{M}}-\mathrm{A}_{\mathrm{CN}}}{\mathrm{A}_{\mathrm{CP}}-\mathrm{A}_{\mathrm{CN}}} * 100
$$

where: $\mathrm{A}$ = absorbance, $\mathrm{M}$ = sample, $\mathrm{CN}$ = negative control, $\mathrm{CP}$ = positive control.

The results were plotted to obtain the hemolytic activity curve (\%) vs. concentration of yeast extract.

\subsection{Statistical Analysis}

The experimental design is based on the factorial method $2^{3}$, which consists of two independent variables: $\mathrm{MB}$ concentration and the growth temperature of the removal process with a study of three levels for each variable according to the values reported in Table 1. 
Table 1. Levels and variables involved in the study.

\begin{tabular}{cccc}
\hline Variable Factor & Low Level & Medium Level & High Level \\
\hline $\mathrm{MB} *$ concentration $(\mathrm{ppm})$ & 50 & 100 & 200 \\
Temperature $\left({ }^{\circ} \mathrm{C}\right)$ & 25 & 30 & 35 \\
\hline
\end{tabular}

* MB: Methylene blue.

In order to evaluate the interactions of the variables in relation to the MB bioremediation, the experimental data obtained were processed using the analysis of variance (ANOVA). For the ANOVA study, we used Microsoft Excel statistics. This methodology examines data from repeated assays during which both factors and levels are varied.

\section{Results and Discussions}

\subsection{Effect of $M B$ Concentration and the Growth Temperature on the Removal Process}

The results of the removal experiments are presented in Figure 1. Furthermore, in Appendix A (Figure A1) we show the photographic tracking of the biodegradation test of MB dye for $48 \mathrm{~h}$ (50 ppm and $30^{\circ} \mathrm{C}$ ). In all cases examined, we determined that there was a reduction, depending on the temperature and concentration combination used; however, different percentages of these reductions were observed. For high concentrations (100 and $200 \mathrm{ppm}$ ) during the first $12 \mathrm{~h}$, the removal percentage was lower ( $12 \%$ and $3 \%$, respectively), compared to MB concentration of $50 \mathrm{ppm}$ ( $45 \%$ of dye removal). The initial MB concentration plays a determinant role for optimal removal, since the increase in the concentration of the dye decreases the rate of degradation, probably due to the toxic effect of the dye on the organism $[25,26]$. In addition, high concentrations of dyes cause inhibition of the metabolic processes of microorganisms [27]. Nevertheless, the toxic effect could be modified (i.e., decreased) if more yeast is added to the solution, as a result of the constant ratio between the MB concentration and the yeast content.

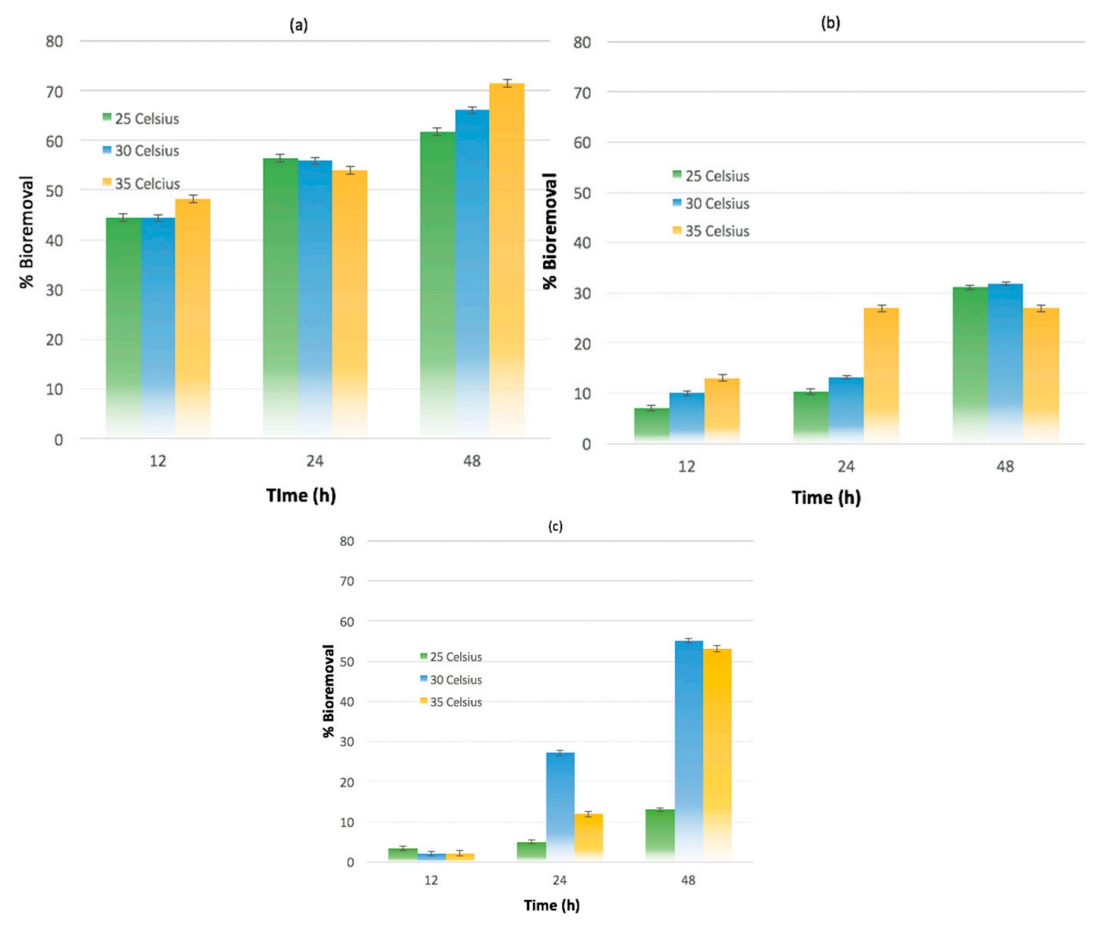

Figure 1. Removal percentages of MB with initial concentration of (a) 50 parts per million (ppm); (b) 100 ppm; (c) 200 ppm by exposition to yeast G. geotrichum KL20A at three different temperatures during the $48 \mathrm{~h}$. 
Previously, it has been determined that decolorization of a mixture of dyes by G. geotrichum was greatly affected by the addition of various carbon and nitrogen sources, instead of the yeast load [23]. Also, it has been reported that carbon and nitrogen sources have an important influence on the extent of discoloration using microorganisms. Different metabolic characteristics in the microorganisms lead to differences in the uptake of sources, and this also will have an effect on the azo dye discoloration [28-30]. On the other hand, dyes are generally deficient in carbon, and biodegradation without an extra carbon source would be very difficult. For that reason, we used YPD-broth to support cell growth, as evidenced by the hemocytometer count. Carbon sources have two purposes: as sources of energy for the growth of the microorganisms and as electron donors, which are necessary to break bonds [31]. All of these observations suggest that in the future, it will be very important to vary carbon and nitrogen sources to be able to study the effect of the discoloration of different dyes, as well as the effect of the dye structure. However, we found that based on the conditions used in this study, there was an initial efficient load of yeast for a discoloration higher than $70 \%$. Additionally, Figure 1 shows that the best biodegradation results are obtained at $35{ }^{\circ} \mathrm{C}(71.5 \%+/-0.8 \%)$. This result may be correlated with two effects. Firstly, to the optimum temperature for the enzymatic activity in many cells, which is normally placed between 35 and $40{ }^{\circ} \mathrm{C}$. Secondly, the result could be related to the mass transfer rate of the dye, since at higher temperatures the viscosity of the solution containing the dye is decreased, increasing the diffusion rate of the dye molecules through the boundary of the outer layer, while at low temperatures this process is slower, decreasing the removal percentage [32].

All the results shown in Figure 1 verify that under the above-mentioned conditions, the yeast $G$. geotrichum presents bioremediation properties towards MB dye.

In order to statistically confirm the observed results, a quantitative study was carried out to determine the respective influence of each independent parameter on the response variable (percentage removal). For this study, the analysis of variance of two factors with three replicates per level was used. The combined effects and the percentage of removal (\%) obtained from Figure 1 are listed in Table 2.

Table 2. Effect of the initial dye concentration variable and temperature on the percentage (\%) in MB bioremediation from data of Figure 1.

\begin{tabular}{cccc}
\hline Concentration $\mathbf{M B}(\mathbf{p p m})$ & $\mathbf{2 5}{ }^{\circ} \mathbf{C}$ & $\mathbf{3 0}{ }^{\circ} \mathbf{C}$ & $\mathbf{3 5}{ }^{\circ} \mathbf{C}$ \\
\hline \multirow{2}{*}{200} & 9.1 & 62.0 & 58.9 \\
& 23.7 & 71.4 & 56.1 \\
& 6.2 & 57.0 & 44.3 \\
\hline \multirow{2}{*}{100} & 27.7 & 27.7 & 26.5 \\
& 32.4 & 32.4 & 27.4 \\
& 35.1 & 35.1 & 26.7 \\
\hline \multirow{2}{*}{50} & 58.2 & 70.7 & 66.2 \\
& 63.6 & 64.7 & 71.7 \\
& 63.4 & 62.8 & 76.6 \\
\hline
\end{tabular}

${ }^{1}$ This value corresponds to methylene blue (MB) \% bioremoval after $48 \mathrm{~h}$ to exposition to G. geotrichum KL20A.

We used ANOVA assay to study the effect of each factor (MB concentration and growth temperature), and the F-distribution (F) was used to determine the statistical effect of each factor. If $\mathrm{F}$ Value $>\mathrm{F}$ critical Value, then the studied parameter had a statistically significant effect on removal percentage. Table 3 lists the ANOVA results obtained from data of Figure 1; theoretical aspects can be found in reference [33]. 
Table 3. Results of analysis of variance (ANOVA) obtained from data of Figure 1.

\begin{tabular}{ccccccc}
\hline Origin of Variations & $\begin{array}{c}\text { Sum of } \\
\text { Squares }\end{array}$ & $\begin{array}{c}\text { Degrees of } \\
\text { Freedom }\end{array}$ & $\begin{array}{c}\text { Average of } \\
\text { Squares }\end{array}$ & F-Value & Probability & F-Critical Value \\
\hline Sample $^{*}$ & 6132.4 & 2 & 3066.2 & 98.6 & $2.0 \times 10^{-10}$ & 3.5 \\
Level $^{* *}$ & 1618.5 & 2 & 809.3 & 26.0 & $4.9 \times 10^{-6}$ & 3.5 \\
Interaction $^{* * *}$ & 2586.1 & 4 & 646.5 & 20.8 & $1.5 \times 10^{-6}$ & 2.9 \\
\hline
\end{tabular}

${ }^{*}$ Factor: This parameter determines if each factor (temperature and BM concentration) had a statistically significant effect on removal percentage; ${ }^{* *}$ Level: This parameter determines if each level $\left(25,30\right.$, and $35^{\circ} \mathrm{C}$ for temperature) and $(50,100$, and $250 \mathrm{ppm}$ for BM concentration) had a statistically significant effect on removal percentage; *** Interaction: This parameter determines if the interaction between two factors (temperature and MB concentration) had a statistically significant effect on removal percentage.

The results indicate that in all cases the factor $\mathrm{F}$ was significantly higher than the critical value, indicating that both factors studied (temperature and $\mathrm{MB}$ concentration) and the levels of variation for each factor had a statistically significant effect on the results of the biodegradation tests. The results validated the observations made in the previous sections and it is confirmed that the optimum removal conditions were achieved for a load of $50 \mathrm{ppm}$ of $\mathrm{MB}$ dye and a temperature of $35^{\circ} \mathrm{C}$, which does not deactivate the enzymatic system of the yeast, reaching a percentage of $71.5 \%$ removal of the MB.

\subsection{Effect of $\mathrm{pH}$ in the Removal Process}

Once the optimum conditions of operation for the bioremoval process were established (50 ppm, $\left.35^{\circ} \mathrm{C}\right)$, we carried out a study of the $\mathrm{pH}$ medium effect under these conditions. Three $\mathrm{pH}$ values $(5,7$, and 9) were evaluated. Figure 2 shows the effects of the $\mathrm{pH}$ based on the percentage of biodegradation. As shown, the $\mathrm{pH}$ is a critical factor for $\mathrm{MB}$ biodegradation. It has been suggested that microbial cells are significantly affected by the $\mathrm{pH}$ of their immediate environment because they apparently have no mechanism for adjusting their internal $\mathrm{pH}$ [34].

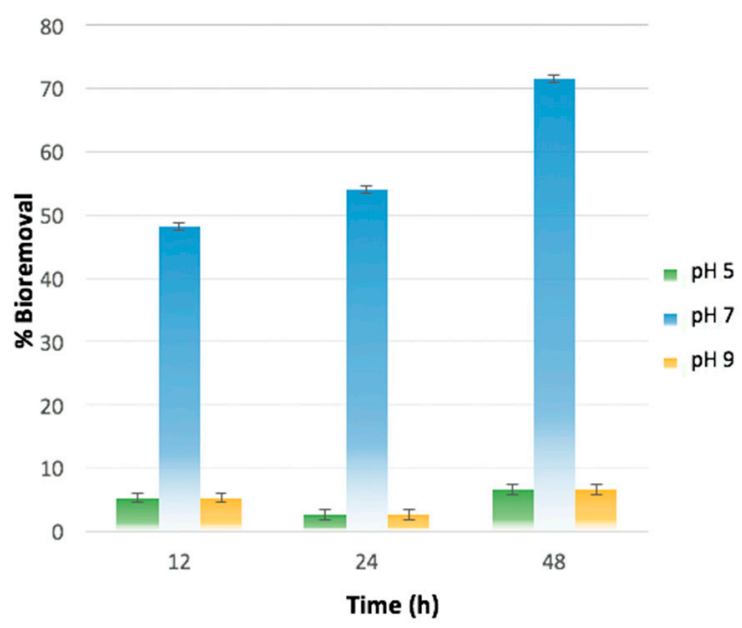

Figure 2. Effect of the $\mathrm{pH}$ on the biodegradation of methylene blue (MB) dye at the initial $\mathrm{MB}$ concentration (50 ppm), and at the temperature of $35^{\circ} \mathrm{C}$.

The $\mathrm{pH}$ of dyes discharged in wastewater varies greatly as a result of their $\mathrm{pH}$ dependent nature. It is well known that the interaction between sorbate and sorbent is also affected by the $\mathrm{pH}$ of an aqueous medium in two ways: firstly, dyes are complex aromatic organic compounds having different functional groups and different ionization potentials at varying $\mathrm{pH}$, which generates a net charge that depends on the $\mathrm{pH}$ of the solution. Secondly, the surface of the biosorbent consists of biopolymers with many functional groups, so the net charge on biosorbent is also $\mathrm{pH}$ dependent. Therefore, the interaction between dye molecules and biosorbent is a combined result of charges on dye molecules and the surface of the biosorbent [35]. With an increase in $\mathrm{pH}$, the net negative charge of the biosorbent 
increases due to deprotonation of different functional groups [35-37]. However, it has been previously reported that G. geotrichum can decolorize Brilliant blue $\mathrm{G}$ dye at a $\mathrm{pH}$ between 5 to 9, while at $\mathrm{pH}$ 3 it has a very low activity, probably due to a loss of the active conformation in the enzymes at low $\mathrm{pH}$ (protonation of functional groups by hydrogen ions, losing their activity) [38]. Adsorption and enzymatic activity are dependent on the $\mathrm{pH}$ [39]. It has been evidenced that the extent of discoloration is influenced by the $\mathrm{pH}$ of the media, as well as that the $\mathrm{pH}$ affects the color of the solution and the solubility of the dye [40]. For example, Aspergillus fumigatus decolorates $90 \%$ of a real textile effluent containing reactive textile dyes including Reactive Black RC, Reactive Yellow HF2-GL, Reactive Blue BGFN, Reactive Black B-150 and Reactive Red A-6BF at values of 3, 78\% at $\mathrm{pH} 5$ and $55 \%$ at $\mathrm{pH} 8$ [41]. For these reasons, we selected the $\mathrm{pH}$ range between 5 and 9 for the study of the optimal $\mathrm{pH}$ solution.

At pH 7 a higher bioremoval percentage (71.5\%) is reached than at pH 5 and 9 (6\% and 12\%), respectively. These results are in agreement with other reports; for example, discoloration of mixtures of structurally different dyes at $\mathrm{pH} 7$ and at $30^{\circ} \mathrm{C}$ in $24 \mathrm{~h}$ by action of G. geotrichum MTCC 1360 was reported by Waghmode et al. [23]. Furthermore, these authors reported $87 \%$ discoloration of the azo Rubine GFL dye (50 ppm) at $30{ }^{\circ} \mathrm{C}$, and $\mathrm{pH}$ of 7 in $96 \mathrm{~h}$ using G. geotrichum MTCC 1360, (3.0 g malt extract, $3.0 \mathrm{~g}$ yeast extract, $5.0 \mathrm{~g}$ peptone, and $10.0 \mathrm{~g}$ glucose, per liter) [42].

\subsection{Kinetic of the Bioremoval Process}

In order to simulate experimental results of MB kinetic removal, we used a pseudo-first-order model according to Equation (2):

$$
\mathrm{r}=-\frac{\mathrm{dC}}{\mathrm{dt}}=\mathrm{k}_{\mathrm{t}}[\mathrm{C}]
$$

Here, $r$ is the rate of dye removal, $k_{t}$ is the constant rate of the process $\left(h^{-1}\right),[C]$ is the MB concentration (ppm). Integration of (1) yields:

$$
\begin{gathered}
{[C]=[C]_{\mathrm{o}} \mathrm{e}^{-\mathrm{k}_{\mathrm{t}} * \mathrm{t}}} \\
\ln \left(\frac{[\mathrm{C}]_{\mathrm{t}}}{[\mathrm{C}]_{\mathrm{o}}}\right)=-\mathrm{k}_{\mathrm{t}} * \mathrm{t}
\end{gathered}
$$

Figure 3a shows the results of the kinetic study and the percentages of removal of MB with an initial concentration of $50 \mathrm{ppm}$ by action of the yeast G. geotrichum KL20A at $35^{\circ} \mathrm{C}$. A steep slope is observed for the first $24 \mathrm{~h}$, indicating a faster rate in the removal, while the slope changes to a constant value close to the maximum removal. It is known that the removal is faster at low concentrations of the dye [39], in this case $\mathrm{MB}$, thus in this investigation we used the following conditions for the removal of the $\mathrm{MB}$ dye: a temperature of $35^{\circ} \mathrm{C}$ and a $\mathrm{MB}$ concentration of $50 \mathrm{ppm}$, using a cell concentration of $3.2 \times 10^{7}$ cells $/ \mathrm{mL}$ of the yeast. Reports in the literature suggest that the several biological species that are studied from the physicochemical point of view follow a pseudo-first order model [43]. Therefore, using such a model, the regression analysis was performed (Figure 3) and the process rate constant was obtained. Figure $3 \mathrm{~b}$ shows the results after utilizing the kinetic model (Equation (4)). The value obtained for the kinetic constant of the MB removal process by G. geotrichum KL20A at $35^{\circ} \mathrm{C}$ was $2.2 \times 10^{-2} \mathrm{~h}^{-1}$ corresponding to a half time for biotransformation of $31.2 \mathrm{~h}$. This value of the kinetic constant is considerably higher than that obtained for other species for the degradation of pollutants: (a) the degradation of polyethoxylates by bacteria, which reported a $\mathrm{k}_{\mathrm{t}}$ value of $7.2 \times 10^{-3} \mathrm{~h}^{-1}$ a half time for biotransformation of $96 \mathrm{~h}$ [44]; (b) the removal of disperse blue with Klebsiella sp., yields a $\mathrm{k}_{\mathrm{t}}$ value of $1.0 \times 10^{-3} \mathrm{~h}^{-1}$ for a reaction time of $160 \mathrm{~h}$ [45]. 

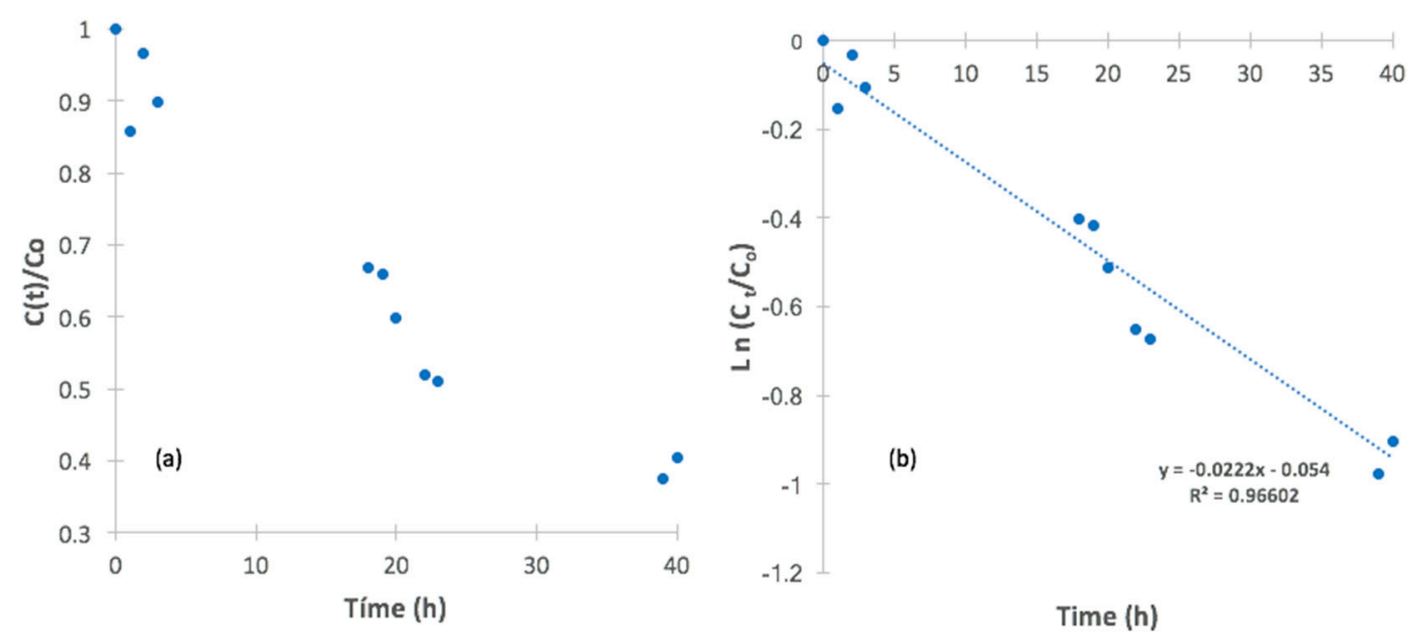

Figure 3. (a) Kinetics of bioremediation of methylene blue (MB) at an initial concentration of $50 \mathrm{ppm}$ per action of the yeast G. geotrichum KL20A at $35^{\circ} \mathrm{C}$. (b) Model L-H on kinetic data of MB removal for the yeast at an initial concentration of $50 \mathrm{ppm}$, temperature at $35^{\circ} \mathrm{C}$ and $\mathrm{pH} 7.0$.

\subsection{Citotoxicity Test}

The cytotoxicity test based on the hemolytic reaction is a highly reliable test in the determination of the cytotoxicity of extracts that, in one way or another, may come into contact with human beings [46]. It can be observed in Figure 4 that the percentage of hemolysis of the final extracts obtained after the discoloration of MB dye experiments was lower than what was obtained for MB solutions, indicating a lower cytotoxicity property for the extracts as compared to the MB solutions. It is important to assess cytotoxicity of the final extracts, since the metabolites produced from dye degradation are, in many cases, more toxic than the parent dye. For example, the products of the oxidation of indigo blue via electro-incineration and chemical coagulation with $\mathrm{Al}_{2}\left(\mathrm{SO}_{4}\right)_{3}$ are more toxic than the parent dye [31]. It is important to note that the extract without purification procedures (to remove medium and yeast) is much less cytotoxic (less percentage of hemolysis) compared to the original solution of the MB. The metabolites produced from dye degradation are, in many cases, more toxic than the parent dye [39]. Several azo dyes and the amines from their degradation have shown mutagenic responses in Salmonella and mammalian assay systems, and their toxicity depends on the nature and position of the substituents in the molecule [47]. Therefore, it is very important for any bioremediation technology to evaluate the toxicity of the pollutants and metabolites formed after dye degradation in order to study the feasibility of the method [48]. Toxicity should be evaluated using various methodologies with respect to phytotoxicity, ecotoxicity, genotoxicity, mutagenicity, acute toxicity, microbial toxicity, and toxicity on invertebrates. Normally, the test chosen corresponds to those that are more economic or accessible in terms of the time and feasibility to test the samples [39]. However, we did not investigate the mechanism of dye degradation, which will be the subject of a forthcoming study, with the identification of some metabolites produced after the biodegradation process and different toxicity assays, including the oxidative stress response. Nevertheless, the cytotoxicity analysis of the final extracts resulting from the degradation process (without any further purification or extraction process) demonstrated a substantial reduction of the cytotoxicity to human erythrocytes, a result that deserves a deeper investigation, since normally it is the phytotoxicity of the extracts that is evaluated. Phytotoxicity of the final extracts has been observed to decrease for G. geotrichum bioremediation processes. For example, a consortium-GB containing two microorganisms, G. geotrichum MTCC 1360 and Bacillus sp. VUS, was able to degrade the sulfur-containing dye Brilliant Blue G optimally at $\mathrm{pH} 9$ and at $50{ }^{\circ} \mathrm{C}$, and the phytotoxicity test revealed the nontoxic nature of the metabolites resulting from the degradation process. In another study, G. geotrichum MTCC 1360, showed 88\% ADMI (American Dye Manufacturing Institute) removal of the mixture of structurally different dyes 
(Remazol red, Golden yellow HER, Rubine GFL, Scarlet RR, Methyl red, Brown 3 REL, Brilliant blue) (70 mg L ${ }^{-1}$ ) within $24 \mathrm{~h}$ at $30^{\circ} \mathrm{C}$ and $\mathrm{pH} 7.0$ under shaking conditions (120 rpm). The phytotoxicity study indicated the conversion of the complex dye molecules into simpler oxidizable products having a less toxic nature.

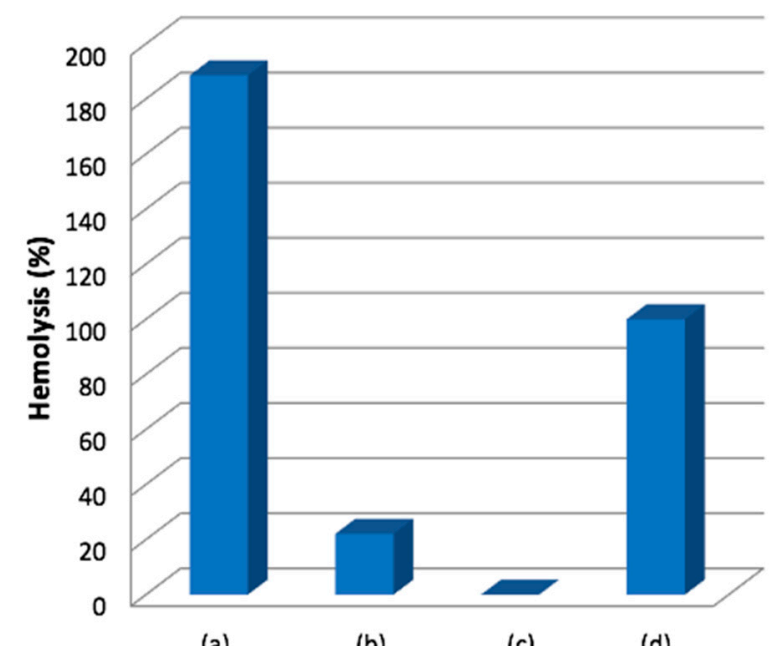

(a)

(b)

(c)

(d)

Figure 4. Comparison of hemolytic activity (\%) to: (a) methylene blue (MB), (b) yeast extracts obtained from MB removal tests, (c) negative control (phosphate-buffer-treated erythrocytes, PBS) and (d) positive control (Triton-X-100).

\section{Conclusions}

The removal of the MB dye at different initial loads (50 ppm, 100 ppm, and 200 ppm) was evaluated using a yeast strain G. geotrichum KL20A with an initial concentration of $3.2 \times 10^{7}$ cells $/ \mathrm{mL}$ for a reaction time of $48 \mathrm{~h}$ at 25,30 , and $35^{\circ} \mathrm{C}$. Results indicated that the increasing temperature in the study range had a positive effect on the removal process; $76.6 \%$ removal was obtained at the highest temperature of $35^{\circ} \mathrm{C}$, with a dye concentration of $50 \mathrm{ppm}$. On the other hand, the $\mathrm{MB}$ concentration had an adverse effect on the removal process. The highest removal percentage was obtained at the lowest $\mathrm{MB}$ concentration, as other authors have already demonstrated; this is presumed to be due to intoxication of the microorganism once the concentration increases. The study of kinetics allowed us to calculate the value of the kinetic constant of the MB removal process by G. geotrichum KL20A at optimal conditions. The kinetic study yielded a rate constant $2.2 \times 10^{-2} \mathrm{~h}^{-1}$ and a half time for biotransformation of $31.2 \mathrm{~h}$. The hemolytic reaction test is considered acceptable and favorable, since the hemolytic activity (\% hem) was the lowest percentage reported for the positive control and for the initial MB. It is important to note that the final sample of MB obtained after the yeast treatment is much less cytotoxic (less\% hemolysis) compared to the initial MB solution without any yeast treatment, which demonstrated that G. geotrichum KL20 was effective to remove MB with a substantial reduction of the cytotoxicity to human erythrocytes.

All of the results confirmed that G. geotrichum KL20 can be used for the removal of effluents with MB dye loads, but it would be valuable in future studies to compare the concentrations used here with the concentrations of $\mathrm{MB}$ in real streams of wastewater.

Author Contributions: Conceptualization, M.C., C.D.G.-T., W.V. and C.C.-L.; methodology, M.C., C.D.G.-T. and W.V.; validation, M.C., C.D.G.-T. and W.V.; formal analysis, M.C.,C.D.G.-T. and W.V.; M.C.,C.D.G.-T. and W.V.; C.D.G.-T.,W.V. and C.C.-L.; data curation, M.C.,C.D.G.-T. and W.V.; writing-original draft preparation, M.C.,C.D.G.-T. and W.V.; writing-review and editing, M.C.,C.D.G.-T.,W.V. and C.C.-L.; visualization, X.X.; supervision, C.D.G.-T. and W.V.; project administration, C.D.G.-T. and W.V.; funding acquisition, C.D.G.-T.,W.V. and C.C.-L.

Funding: This research was funded by Universidad del Atlántico, First internal call for support for the development of degree work in training research-undergraduate and graduate level 2018. 
Acknowledgments: The authors thank to the Faculty of Bioscience and Technology for Food, Agriculture and Environment, University of Teramo for the donation of the strain of Galactomyces geotrichum KL20 used in the present study.

Conflicts of Interest: The authors declare no conflict of interest.

\section{Appendix A}

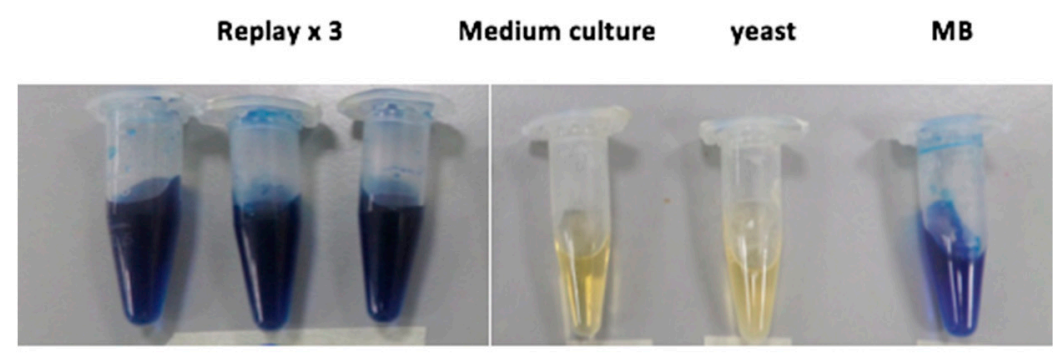

(a)

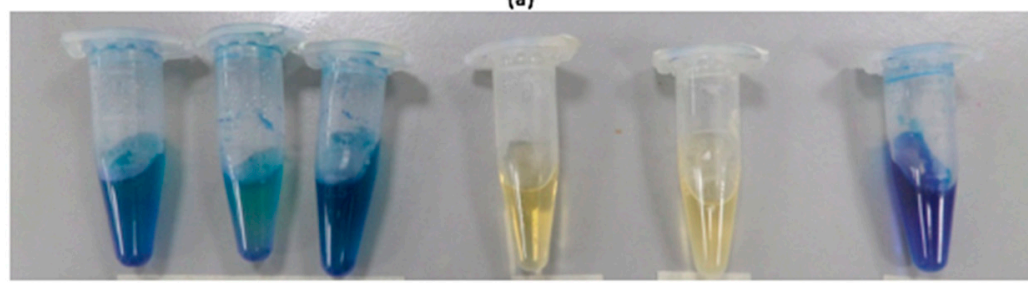

(b)

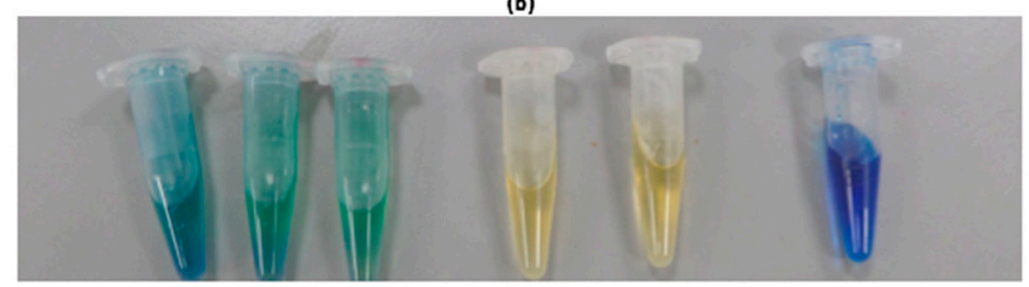

(c)

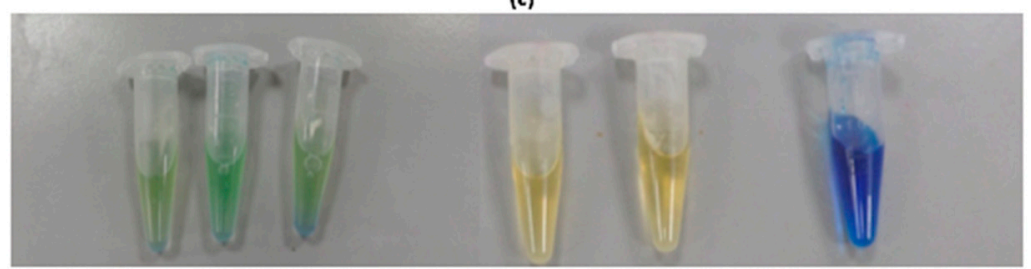

(d)

Figure A1. Tests of biodegradation of MB dye by the action of the yeast Galactomyces geotrichum KL20A. (a) Time zero hours, (b) Time $12 \mathrm{~h}$, (c) Time $24 \mathrm{~h}$, (d) Time $48 \mathrm{~h}$, (MB concentration was 50 ppm and temperature was $\left.30^{\circ} \mathrm{C}\right)$. The images on the left correspond to replays $(\times 3)$ of the degradation experiments. The images on the right correspond to the controls used in order of yeast, culture medium (YPD-broth).

\section{References}

1. Zaharia, C.; Suteu, D. Textile Organic Dyes-Characteristics, Polluting Effects and Separation/Elimination Procedures from Industrial Effluents-A Critical Overview. In Organic Pollutants Ten Years After the Stockholm Convention-Environmental and Analytical Update; Puzyn, T., Ed.; InTech: Beijing, China, 2012; pp. 55-86. ISBN 978-953-307-917-2.

2. Shah, K. Biodegradation of azo dye compounds. Int. Res. J. Biochem. Biotechnol. 2014, 1, 5-13.

3. Ginimuge, P.R.; Jyothi, S.D. Methylene blue: Revisited. J. Anaesthesiol. Clin. Pharmacol. 2010, 26, 517-520. [PubMed]

4. Oz, M.; Lorke, D.E.; Hasan, M.; Petroianu, G.A. Cellular and molecular actions of Methylene Blue in the nervous system. Med. Res. Rev. 2011, 31, 93-117. [CrossRef] [PubMed] 
5. Xu, C.; Rangaiah, G.P.; Zhao, X.S. Photocatalytic Degradation of Methylene Blue by Titanium Dioxide: Experimental and Modeling Study. Ind. Eng. Chem. Res. 2014, 53, 14641-14649. [CrossRef]

6. El-Ashtoukhy, E.-S.Z.; Fouad, Y.O. Liquid-liquid extraction of methylene blue dye from aqueous solutions using sodium dodecylbenzenesulfonate as an extractant. Alex. Eng. J. 2015, 54, 77-81. [CrossRef]

7. Garg, V.K.; Amita, M.; Kumar, R.; Gupta, R. Basic dye (methylene blue) removal from simulated wastewater by adsorption using Indian Rosewood sawdust: A timber industry waste. Dye Pigment. 2004, 63, 243-250. [CrossRef]

8. Xi, Y.; Shen, Y.; Yang, F.; Yang, G.; Liu, C.; Zhang, Z.; Zhu, D. Removal of azo dye from aqueous solution by a new biosorbent prepared with Aspergillus nidulans cultured in tobacco wastewater. J. Taiwan Inst. Chem. Eng. 2013, 44, 815-820. [CrossRef]

9. Robinson, T.; McMullan, G.; Marchant, R.; Nigam, P. Remediation of dyes in textile effluent: A critical review on current treatment technologies with a proposed alternative. Bioresour. Technol. 2001, 77, 247-255. [CrossRef]

10. Kandisa, R.V.; KV, N.S.; Shaik, K.B.; Gopinath, R. Dye Removal by Adsorption: A Review. J. Bioremed. Biodegrad. 2016, 7, 1-4. [CrossRef]

11. Dzionek, A.; Wojcieszyńska, D.; Guzik, U. Natural carriers in bioremediation: A review. Electron. J. Biotechnol. 2016, 23, 28-36. [CrossRef]

12. Mosa, K.A.; Saadoun, I.; Kumar, K.; Helmy, M.; Dhankher, O.P. Potential Biotechnological Strategies for the Cleanup of Heavy Metals and Metalloids. Front. Plant Sci. 2016, 7, 303. [CrossRef] [PubMed]

13. Jadhav, U.U.; Dawkar, V.V.; Telke, A.A.; Govindwar, S.P. Decolorization of Direct Blue GLL with enhanced lignin peroxidase enzyme production in Comamonas sp. UVS. J. Chem. Technol. Biotechnol. 2009, 84, 126-132. [CrossRef]

14. Maldonado, R.R.; Lopes, D.B.; Aguiar-Oliveira, E.; Kamimura, E.S.; Bacedo, G.A. A Review on Geotrichum Lipases: Production, Purification, Immobilization and Applications. Chem. Biochem. Eng. Q. 2016, 30, 439-454. [CrossRef]

15. Noelia, S.V. Selection of Geotrichum Candidum Strains Isolated from Artisanal Cheeses in Order to Obtain Technologically Useful Co-Starters to Be Used in Cheese-Making; Universidad de León: León, Spain, 2016.

16. Larone Davise, H. Medically Important Fungi: A Guide to Identification, 5th ed.; ASM Press: Washington, DC, USA, 2014; Volume 45, ISBN 978-1555816605.

17. Tores, L.F. Clonación, Expresión y Evolución Molecular de la Lipasa I de Galactomices Geotrichum, 1st ed.; Editorial de la Universidad de Granada: Granada, Spain, 2005; ISBN 84-338-3613-7.

18. Grygier, A.; Myszka, K.; Rudzińska, M. Galactomyces Geotrichum-Moulds from dairy Products with High Biotechnological Potential. Acta Sci. Pol. Technol. Aliment. 2017, 16, 5-16. [CrossRef] [PubMed]

19. Jadhav, S.U.; Kalme, S.D.; Govindwar, S.P. Biodegradation of Methyl red by Galactomyces geotrichum MTCC 1360. Int. Biodeterior. Biodegrad. 2008, 62, 135-142. [CrossRef]

20. Waghmode, T.R.; Kurade, M.B.; Kabra, A.N.; Govindwar, S.P. Biodegradation of Rubine GFL by Galactomyces geotrichum MTCC 1360 and subsequent toxicological analysis by using cytotoxicity, genotoxicity and oxidative stress studies. Microbiology 2012, 158, 2344-2352. [CrossRef]

21. Govindwar, S.P.; Kurade, M.B.; Tamboli, D.P.; Kabra, A.N.; Kim, P.J.; Waghmode, T.R. Decolorization and degradation of xenobiotic azo dye Reactive Yellow-84A and textile effluent by Galactomyces geotrichum. Chemosphere 2014, 109, 234-238. [CrossRef]

22. Chaves-López, C.; Tofalo, R.; Serio, A.; Paparella, A.; Sacchetti, G.; Suzzi, G. Yeasts from Colombian Kumis as source of peptides with Angiotensin I converting enzyme (ACE) inhibitory activity in milk. Int. J. Food Microbiol. 2012, 159, 39-46. [CrossRef]

23. Waghmode, T.R.; Kurade, M.B.; Govindwar, S.P. Time dependent degradation of mixture of structurally different azo and non azo dyes by using Galactomyces geotrichum MTCC 1360. Int. Biodeterior. Biodegrad. 2011, 65, 479-486. [CrossRef]

24. Zhen, Z.; Liu, X.; Huang, T.; Xi, T.; Zheng, Y. Hemolysis and cytotoxicity mechanisms of biodegradable magnesium and its alloys. Mater. Sci. Eng. C 2015, 46, 202-206. [CrossRef]

25. Saratale, R.G.; Saratale, G.D.; Chang, J.S.; Govindwar, S.P. Decolorization and biodegradation of textile dye Navy blue HER by Trichosporon beigelii NCIM-3326. J. Hazard. Mater. 2009, 166, 1421-1428. [CrossRef] [PubMed] 
26. Jadhav, U.U.; Dawkar, V.V.; Tamboli, D.P.; Govindwar, S.P. Purification and characterization of veratryl alcohol oxidase from Comamonas sp. UVS and its role in decolorization of textile dyes. Biotechnol. Bioprocess Eng. 2009, 14, 369-376. [CrossRef]

27. Kozliak, E.I.; Paca, J. Foreword. J. Environ. Sci. Heal. Part A 2012, 47, 919. [CrossRef] [PubMed]

28. Khelifi, E.; Ayed, L.; Bouallagui, H.; Touhami, Y.; Hamdi, M. Effect of nitrogen and carbon sources on Indigo and Congo red decolourization by Aspergillus alliaceus strain 121C. J. Hazard. Mater. 2009, 163, 1056-1062. [CrossRef]

29. Tony, B.D.; Goyal, D.; Khanna, S. Decolorization of textile azo dyes by aerobic bacterial consortium. Int. Biodeterior. Biodegrad. 2009, 63, 462-469. [CrossRef]

30. Levin, L.; Melignani, E.; Ramos, A.M. Effect of nitrogen sources and vitamins on ligninolytic enzyme production by some white-rot fungi. Dye decolorization by selected culture filtrates. Bioresour. Technol. 2010, 101, 4554-4563. [CrossRef]

31. Solís-Oba, M.; Eloy-Juárez, M.; Teutli, M.; Nava, J.L.; González, I. Comparison of advanced techniques for the treatment of an indigo model solution: Electro incineration, chemical coagulation and enzymatic. Rev. Mex. Ing. Quim. 2009, 8, 275-282.

32. Ali, N.; Hameed, A.; Ahmed, S. Role of brown-rot fungi in the bioremoval of azo dyes under different conditions. Braz. J. Microbiol. 2010, 41, 907-915. [CrossRef]

33. Jackson, S.A.; Brashers, D.E. Random Factors in ANOVA; Sage Publications: Thousand Oaks, CA, USA, 1994; ISBN 9780803950900.

34. Bhattacharya, S.; Das, A. Mycoremediation of Congo Red Dye By Filamentous Fungi. Braz. J. Microbiol. 2011, 42, 1526-1536. [CrossRef]

35. Harris, P.O.; Ramelow, G.J. Binding of metal ions by particulate biomass derived from Chlorella vulgaris and Scenedesmus quadricauda. Environ. Sci. Technol. 1990, 24, 220-228. [CrossRef]

36. Schiewer, S.; Volesky, B. Modeling of the proton-metal ion exchange in biosorption. Environ. Sci. Technol. 1995, 29, 3049-3058. [CrossRef] [PubMed]

37. Kapoor, A.; Viraraghavan, T.; Cullimore, D.R. Removal of heavy metals using the fungus Aspergillus niger. Bioresour. Technol. 1999, 70, 95-104. [CrossRef]

38. Jadhav, S.U.; Jadhav, M.U.; Kagalkar, A.N.; Govindwar, S.P. Decolorization of Brilliant Blue G dye mediated by degradation of the microbial consortium of Galactomyces geotrichum and Bacillus sp. J. Chin. Inst. Chem. Eng. 2008, 39, 563-570. [CrossRef]

39. Solís, M.; Solís, A.; Pérez, H.I.; Manjarrez, N.; Flores, M. Microbial decolouration of azo dyes: A review. Process Biochem. 2012, 47, 1723-1748. [CrossRef]

40. Das, D.; Charumathi, D.; Das, N. Bioaccumulation of the synthetic dye Basic Violet 3 and heavy metals in single and binary systems by Candida tropicalis grown in a sugarcane bagasse extract medium: Modelling optimal conditions using response surface methodology (RSM) and inhibition kinet. J. Hazard. Mater. 2011, 186, 1541-1552. [CrossRef] [PubMed]

41. Jin, X.-C.; Liu, G.-Q.; Xu, Z.-H.; Tao, W.-Y. Decolorization of a dye industry effluent by Aspergillus fumigatus XC6. Appl. Microbiol. Biotechnol. 2007, 74, 239-243. [CrossRef] [PubMed]

42. Waghmode, T.R.; Kurade, M.B.; Lade, H.S.; Govindwar, S.P. Decolorization and Biodegradation of Rubine GFL by Microbial Consortium GG-BL in Sequential Aerobic/Microaerophilic Process. Appl. Biochem. Biotechnol. 2012, 167, 1578-1594. [CrossRef]

43. Krishnan, J.; Arvind Kishore, A.; Suresh, A.; Madhumeetha, B.; Gnana Prakash, D. Effect of pH, inoculum dose and initial dye concentration on the removal of azo dye mixture under aerobic conditions. Int. Biodeterior. Biodegrad. 2017, 119, 16-27. [CrossRef]

44. Ruiz, Y.; Medina, L.; Borusiak, M.; Ramos, N.; Pinto, G.; Valbuena, O. Biodegradation of polyethoxylated nonylphenols. ISRN Microbiol. 2013, 2013, 284950. [CrossRef]

45. Catherine, R.; Jimenez, G. Cinética de Degradación de Colorantes Textiles de Diferentes Clases Químicas por hongos y Bacterias Inmovilizados Sobre Fibra DE Agave tequilana Webber var Azul; Universidad Javeriana: Bogotá, Colombia, 2009.

46. De Sena Pereira, V.S.; Silva de Oliveira, C.B.; Fumagalli, F.; da Silva Emery, F.; da Silva, N.B.; de Andrade-Neto, V.F. Cytotoxicity, hemolysis and in vivo acute toxicity of 2-hydroxy-3-anilino-1,4naphthoquinone derivatives. Toxicol. Rep. 2016, 3, 756-762. [CrossRef] 
47. Ferraz, E.R.A.; Umbuzeiro, G.A.; De-Almeida, G.; Caloto-Oliveira, A.; Chequer, F.M.D.; Zanoni, M.V.B.; Dorta, D.J.; Oliveira, D.P. Differential toxicity of Disperse Red 1 and Disperse Red 13 in the Ames test, HepG2 cytotoxicity assay, and Daphnia acute toxicity test. Environ. Toxicol. 2011, 26, 489-497. [CrossRef] [PubMed]

48. Jadhav, S.B.; Phugare, S.S.; Patil, P.S.; Jadhav, J.P. Biochemical degradation pathway of textile dye Remazol red and subsequent toxicological evaluation by cytotoxicity, genotoxicity and oxidative stress studies. Int. Biodeterior. Biodegrad. 2011, 65, 733-743. [CrossRef]

(C) 2019 by the authors. Licensee MDPI, Basel, Switzerland. This article is an open access article distributed under the terms and conditions of the Creative Commons Attribution (CC BY) license (http://creativecommons.org/licenses/by/4.0/). 